\title{
The Impacts of a National Internship Program on Interns' Perceived Leadership, Critical Thinking, and Communication Skills
}

\author{
Dennis W. Duncan, Ph. D. \\ Professor \\ University of Georgia \\ Victoria Birdsong \\ MAL Candidate \\ University of Georgia \\ Nicholas Fuhrman, Ph. D. \\ Associate Professor \\ University of Georgia \\ Abigail Borron, Ph. D. \\ Assistant Professor \\ University of Georgia
}

\begin{abstract}
At perhaps all levels of education, strong leadership skills are often equated with the ability to engage in critical thinking, and effective oral and written communication. The purpose of this study was to identify the self-perceived expansion of animal health interns' leadership, critical thinking and communication competencies using the University of Florida Engagement, Cognitive Maturity, and Innovativeness (UF-EMI) and Leadership Skills Inventory (LSI) assessments. For the UF-EMI, the total mean score of the pre-critical thinking disposition of all interns was 104.73; post-critical thinking disposition was 114.46, an increase of 9.73. Results of the LSI indicate just 70\% accept who they are and don't see themselves as good listeners.
\end{abstract}

\section{Introduction/Literature Review}

College students often have overwhelming concerns when it comes to preparation for employment after graduation (Gault, Redington, \& Schlager, 2000). During their matriculation in college, students have a plethora of opportunities to refine their leadership skills (communication, critical thinking, problem solving, etc.) so as to be more competitive in the marketplace where companies may require prior experience as well as strong leadership skills of new hires. Employers look for prior experience to qualify entry-level professionals and according to a 2015 Forbes article many employers feel that recent graduates are unprepared to join the workforce and are unable to apply knowledge and skills such as critical thinking and communication in a real-world setting (Klebnikov, 2015). A study completed by The Association of American Colleges and Universities (AACU) concluded that a large gap exists between 
college students' feelings about their preparedness level and employers' feelings about college students level of preparedness. The majority of employers felt that recent college graduates are not prepared for the workforce in areas such as critical thinking skills, written and oral communication skills, and working with others in teams (AACU, 2015). The aforementioned skills are often referred to as "soft skills" and may also include team building, conflict resolution, time management, etc.

Soft skills are defined as aspects of social behavior and include communication skills, leadership abilities, and personal qualities such as empathy and friendliness that are required to become successful in life (deRidder, Meysman, Oluwagbemi, \& Abeel, 2014). Additionally, soft skills enable a person the ability to effectively relate to others by way of communication, organization, or written skills (Tyagi \& Tomar, 2013). Brooks et al. (2008) reported that undergraduates seeking employment positions were heavily focused on technical skills and not so much on soft skills. The study concluded that job candidates need to focus more on critical thinking, problem solving, and analytical skills.

Students' ability to solve problems and be resourceful is non-cognitive (soft) skills viewed by some experts as being of the same importance as mathematics and reading (Adams, 2012). Murti (2014) argues that soft skills are developed through prior relationships, (personal and business) which make them harder to teach and evaluate in a classroom setting. According to a survey by the Workforce Solutions Group at St. Louis Community College, employers acknowledge that recent graduates have high technical expertise in given fields; however, over half of the respondents stated that critical thinking, problem solving, and communication/interpersonal skills are areas new hires are lacking in (St. Louis Community College, 2015).

Crawford, Lang, Fink, Dalton, and Fielitz (2011) with support from the Association of Public and Land-grant Universities (APLU) sought to determine which soft skills employers seek in new college graduates. Of seven soft-skill clusters (decision making/problem solving, selfmanagement, teamwork skills, professionalism skills, communication skills, experiences, and leadership skills), the top two ranked by over 250 employers were communication and decisionmaking/problem solving (Crawford et al., 2011). Institutions of higher education that do not provide coursework and/or experiential learning opportunities that strengthen students' soft skills can be blamed for educating a future workforce that is not adequately prepared to face the challenges of global markets. One experiential learning opportunity that has the potential to positively influence the soft skills of college students is structured internship programs that provide valuable, practical experience for entry-level prospects and promotes on the job training (Walker, 2011).

Internships originated in the United States during the early 1900s and the University of Cincinnati is credited with starting the very first internship program in 1906 (Thiel \& Hartley, 1997). Internships are a non-traditional educational approach based on experiential learning (Driscoll, 2006). As defined by Kolb (1984), “... [Experiential] learning is described as a process whereby concepts are derived from and continuously modified by experience" (p.26). The four primary steps within Kolb's model are concrete experience, reflecting on an observation, forming abstract ideas, and active experimentation (Walker, Morgan, Ricketts, \& Duncan, 2007). 
Although those participating in experiential learning may enter the cycle at different stages, the sequence must be followed as illustrated in Figure 1 (Kolb, 1984; Walker et al., 2007).

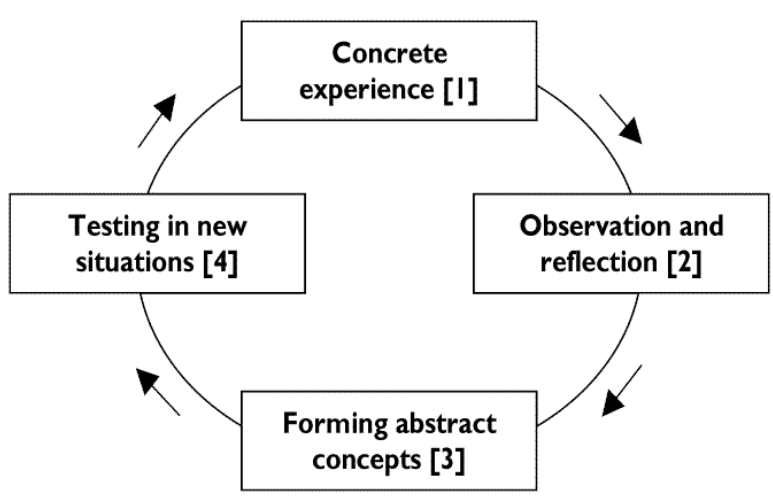

Figure 1. The Experiential Learning Cycle (Kolb, 1984)

As broadly defined, Internships can include a number of experiential learning activities/platforms and range from apprenticeships and cooperative education, to externships and are typically completed while the student is enrolled in an academic degree program (Thiel \& Hartley, 1997). Apprenticeships are a paid position for someone who has decided on a career path and is looking to obtain in-depth knowledge in a specific field. In Europe, youth apprenticeships date back to the early nineteenth century and are still a vital component of European training systems (Olson, 1993; Snell, 1996). Cooperative education or co-op is a paid internship that allows college students to work with professionals in their field of study to enhance academic training (Blair, Milea, \& Hammer, 2004). Externships are typically an unpaid training program offered by educational institutions and private businesses that give students brief practical experiences in their field of study and may be directly tied to a course (Smith, 2013).

The benefits of internship programs to students, colleges and universities, and industry leaders are deep and broad. Internships offer students the opportunity to apply classroom knowledge in a real world context (Mello, 2006; Sides \& Mrvica, 2007), and students who complete internships are able to return to the classroom and share their knowledge and experiences with their peers, and add relevancy to learning (Swift \& Kent, 1999). Additionally, Coco's (2000) study discovered that over ninety percent of respondents denoted that an internship provided an experiential advantage when it came to finding a job. Finally, internships enable students to clarify career goals (Divine, Linrud, Miller, \& Wilson, 2007) and aid them in transitioning from an academic setting to a career workplace setting (Taylor, 1998).

The reputation and visibility of a college or university can be enhanced through internship programs (Coco, 2000) and relationships are fostered with companies in the community by way of internships, as well as nationally, which in turn benefits the institutions (Divine, et al., 2007). Additionally, internship programs may potentially increase enrollment through the attraction of the required offering (Divine, et al., 2007). Finally, institutions that foster and nurture relationships between internship programs hold long-term benefits such as 
increased availability of classroom speakers, increased participation in job fairs, increased contacts for development personnel in various fundraising efforts, and future student placement in internship programs (Coco, 2000; Divine, et al., 2007; Gault, et al., 2000).

Employers benefit from internships by being able to get a glimpse at a student's work ethic without having to hire them (Coco, 2000; Gault, et al., 2000; Knemeyer \& Murphy, 2001) and secure inexpensive and often quality labor (Coco, 2000; Gault, et al., 2000). Additionally, companies can utilize interns during busy times of the year with no long-term commitments (Divine, et al., 2007) and can evaluate potential employees prior to making long-term commitments. Dobratz, Singh, and Abbey (2014) conducted a thorough review of the literature regarding the values of internships for students, institutions, and institutions - their findings are presented in Table 1. 
Table 1

Benefits of internships to....

\begin{tabular}{|c|c|c|}
\hline Students & Institutions & Employers \\
\hline $\begin{array}{l}\text { Potentially earn money while } \\
\text { receiving a learning experience } \\
\text { (Thiel \& Hartley, 1997) }\end{array}$ & $\begin{array}{l}\text { Enhance the qualifications of } \\
\text { professors (Divine, et al., 2007; } \\
\text { Thiel \& Hartley, 1997) }\end{array}$ & $\begin{array}{l}\text { Reduced turnover (Knemeyer } \\
\text { \& Murphy, 2001) }\end{array}$ \\
\hline $\begin{array}{l}\text { Better interpersonal skills } \\
\text { (Beard \& Morton, 1999; } \\
\text { Divine et. Al., 2007; Thiel \& } \\
\text { Hartley, 1997; \& Gault, } \\
\text { Redington \& Schlager, 2000) }\end{array}$ & $\begin{array}{l}\text { Keeping faculty up-to-date on } \\
\text { the community (Divine, et al., } \\
\text { 2007) } \\
\text { Assists in fundraising potential } \\
\text { (Coco, 2000; Gault, Redington, } \\
\text { \& Schlager, 2000) }\end{array}$ & $\begin{array}{l}\text { Ability to evaluate potential } \\
\text { employers prior to full-hire } \\
\text { (Divine et al., 2007; Gault, } \\
\text { Redington, \& Schlager, 2000) } \\
\text { Showing social responsibility } \\
\text { to the community (Thiel \& } \\
\text { Hartley, 1997) }\end{array}$ \\
\hline $\begin{array}{l}\text { Faster job placement and } \\
\text { advancement (Coco, 2000; } \\
\text { Taylor, 1988) } \\
\text { Higher personal as well as } \\
\text { social skills (Page, Geck \& } \\
\text { Wiseman, 1999) } \\
\text { Greater satisfaction (Taylor, } \\
\text { 1988) }\end{array}$ & $\begin{array}{l}\text { Can lead to company donations } \\
\text { (Thiel \& Hartley, 1997) } \\
\text { Enriched classroom conversation } \\
\text { from student interns (Swift \& } \\
\text { Kent, 1999) }\end{array}$ & $\begin{array}{l}\text { Strengthens relationships with } \\
\text { universities (Divine } \text { et al., } \\
\text { 1996) } \\
\text { Highly motivated workers } \\
\text { (Coco, 2000; Gault, } \\
\text { Redington, \& Schlager, 2000) }\end{array}$ \\
\hline $\begin{array}{l}\text { Better equipped and more } \\
\text { qualified (Divine et al., 2007; } \\
\text { Taylor, 1988) } \\
\text { Improved industry knowledge } \\
\text { (Coco, 2000; Divine, et al., } \\
\text { 2007) }\end{array}$ & $\begin{array}{l}\text { Potentially increase enrollment } \\
\text { through the attraction of the } \\
\text { required offering (Divine, et al., } \\
\text { 2007) }\end{array}$ & $\begin{array}{l}\text { Inexpensive resources of } \\
\text { student interns (Coco, 2000) } \\
\text { "Cross fertilization of ideas" } \\
\text { (Thiel \& Hartley, 1997, p. 20) }\end{array}$ \\
\hline $\begin{array}{l}\text { Higher starting salaries } \\
\text { (Taylor, 1988) } \\
\text { More maturity and confidence } \\
\text { (Thiel \& Hartley, 1997) }\end{array}$ & $\begin{array}{l}\text { Employers utilized as a source of } \\
\text { knowledge for classroom } \\
\text { discussion (Thiel \& Hartley, } \\
\text { 1997) }\end{array}$ & $\begin{array}{l}\text { Ability to create brand loyalty } \\
\text { among those involved (Thiel } \\
\text { \& Hartley, 1997) }\end{array}$ \\
\hline $\begin{array}{l}\text { Job acquisition skills (Divine, } \\
\text { 2007) }\end{array}$ & $\begin{array}{l}\text { Attract nontraditional students } \\
\text { (Thiel \& Hartley, 1997) }\end{array}$ & \\
\hline
\end{tabular}

More job offers "(Coco, 2000;

Swift \& Kent, 1999; Taylor,

1988; Divine et al., 2007 (Thiel

\& Hartley, 1997)

Leadership skills (Gault,

Redington \& Schlager, 2000)

*Note. Adapted and used with permission from Dobratz, Singh, \& Abbey (2014)

Although much is known about the pedagogical, personal, professional, and financial values of internships for students, institutions, and employers little is known of the impact of an internship 
with regard to students' perceived communication, critical thinking, and leadership skills; hence, the purpose of this research study.

\section{Theoretical Framework}

This study was organized around two theoretical frameworks - critical thinking as defined and explored by Peter Facione and social cognitive theory as defined by Albert Bandura. Facione's (1990) definition of critical thinking states that "we understand critical thinking to be purposeful, self-regulatory judgment, which results in interpretation, analysis, evaluation, and inference, as well as explanation of the evidential, conceptual, methodological, criteriological, or contextual considerations upon which that judgment is based" (p. 2). From Facione's study the critical thinking skills identified was interpretation, explanation, analysis, evaluation, inference, and self-regulation. In addition, Facione (1990) refers to his identification of critical thinking dispositions, or approaches to life that increases an individual's likelihood to participate in critical thinking. These dispositions include analyticity, self-confidence, inquisitiveness, maturity, open mindedness, systematicity, and truth seeking. Facione, Giancarlo, Facione, and Gainen (1995) described further characteristics of dispositions:

"Inquisitiveness with regard to a wide range of ideas, concern to become and remain well-informed, alertness to opportunities to use critical thinking, trust in the process of reasoned inquiry, self-confidence in one's own abilities to reason, open-mindedness regarding divergent world views, flexibility in considering alternatives and opinions, understanding the opinions of other people, fair-mindedness in appraising reasoning, honesty in facing one's own biases, prejudices, stereotypes, or egocentric tendencies, prudence in suspending, making, or altering judgments, willingness to reconsider and revise views where hones reflection suggests that change is warranted" (p.8).

Dispositions develop over time and are influenced by an individual's surrounding environment. They are strong precursors of critical thinking and even though they can be changed, they often change slowly and over an extended period of time (Irani, et al., 2007).

Engagement, cognitive maturity, and innovativeness - examples of dispositions that can be impacted by a host of variables in one's environment - can be measured via an instrument referred to as the University of Florida Engagement, Cognitive Maturity, Innovativeness (UFEMI): Critical Thinking Disposition Assessment (Ricketts, Williams, \& Priest, 2009). According to Ricketts and Rudd (2005):

“The Engagement disposition measured students' predisposition to look for opportunities to use reasoning; anticipating situations that require reasoning; and confidence in reasoning ability. The Cognitive Maturity (Maturity) disposition measured students' awareness of the complexity of real problems; being open to other points of view; and being aware of their own and others' biases and predispositions. The Innovativeness disposition measured students' predisposition to be intellectually curious and wanting to know the truth" (p. 33).

Given this theoretical framework - according to Facione (1998), a student who experiences an internship is likely to experience analyticity, self-confidence, inquisitiveness, maturity, open 
mindedness, systematicity, and truth-seeking - dispositions of critical thinking. If a student gains those benefits, according to Facione (1998), the student should be able to think more critically.

The second theoretical base for this study is grounded in the social cognitive theorymore specifically self-efficacy. Theorized by Bandura in the 1960's, social cognitive theory explains how learners gain knowledge by observing others within their environments and that learning is more of a social act rather than an individual decision. The assumptions of social cognitive theory are: behavior is purposeful and driven by a goal, individuals are self-reflective, learners are able to self-regulate, and reciprocal determinism takes place (Bandura, 1986, 1977). The three factors that allow one to evaluate behavior change within social cognitive theory (reciprocal determinism) are environment, personal factors, and behavior. Environment refers to the factors that impact a person's behavior and include the physical environment (their physical surroundings) as well as social environment (the people or social situation they are in); personal factors are an individual's self-efficacy towards a behavior; and behavior is the response that the learner receives once they have completed the desired behavior. For the purposes of this study the researchers chose to focus on intern's perceived levels of self-efficacy in regards to communication, leadership, and critical thinking.

Self-efficacy is a primary tenet of social cognitive theory, which explains that behavior is reciprocally influenced by personal factors and the environment (Bandura, 1986). Through this lens, leadership course content and experiences (environment) reciprocally interact with the personal characteristics participants/students bring to the course and expected leadership skills (behavior). According to Bandura $(1977,1986)$ self-efficacy is a person's belief in their own ability to start, perform, and complete specific activities at high levels even in the midst of adversity. Self-efficacy espouses that individuals with high self-efficacy will be competent performers of the skills or activities for which they are efficacious. Therefore, leadership students who are efficacious in leadership skills are likely to exhibit those skills as student or professional leaders.

\section{Methods}

The purpose of this study was to identify the self-perceptions of animal health interns in regard to the expansion of competencies based in communication, leadership, and critical thinking - skills necessary to be an effective intern. The objectives that guided this study were:

1. Identify the demographic characteristics of the animal health interns;

2. Analyze the perception of leadership and life skills focusing on working with others, decision-making, positional leadership, understanding of self, and communication among the interns; and

3. Identify the interns' self-perceived critical thinking skills before and after the completion of a 12 week internship.

The population for this study was a convenience sample consisting of all interns $(N=32)$ employed during a summer-long national animal health internship program that was structured based on the following practices: (1) participants were strongly encouraged to participate in an orientation session to ensure the same expectations and role definitions were in place for all, (2) 
participants were greeted and given presentations by upper level executive employees (i.e. CEO of company, VP of marketing, Director of HR, etc.), (3) participants were provided with an intern supervisor who performed mid-summer checks to assess the interns progress, (4) participants were provided with real work assignments and asked to contribute value to the company at the end of the 12 week program through their projects, (5) participants were encouraged to involve other employees and interns in their summer projects, (6) participants were encouraged to showcase their intern work through company-wide presentations at the conclusion of the internship program, and (7) participants were given the opportunity to conduct exit interviews and provide feedback with the intern coordinator.

Of the 32 interns, 30 chose to participate in the study. The areas of concentration for the animal health interns were home office, food animal sales, companion animal sales, and research and development. All participants were advised of their rights as human subjects and asked to review an Institutional Review Board (IRB) consent form prior to taking the survey - which was distributed as hard copy at the conclusion of the internship program. The quantitative survey instrument consisted of two domains - the University of Florida - Engagement, Cogitative Maturity, Innovativeness (UF-EMI) assessment and the Leadership Skills Inventory (LSI). The retrospective post-test only version of the UF-EMI contained 26 items, each relating to one of the three constructs: engagement, cognitive maturity, and innovativeness. The instrument asked the participant to select a level of agreement with each statement on a Likert-type scale (1=strongly disagree; $5=$ strongly agree). In column one the participant is asked to reflect back to day one of the internship and select their level of agreement for each statement. The same process is asked of each participant at the conclusion of the internship in column two. Reliability coefficents have been calculated on each of the constructs in a previous study and ranged from: engagement $=0.906$, maturity $=0.787$, and innovate $=0.797$ (Irani, et al., 2007).

The Leadership Skills Inventory (LSI) was developed in 1980, tested in 1981 by Carter and Townsend (Townsend, 1981) and revised in 1983 (Townsend \& Carter, 1983). The LSI consists of 21 statements describing various leadership and life skills, which correspond to five internal scales used for analysis: working with others, decision-making, positional leadership, understanding of self, and communication. Respondents are given a Likert-type scale for each statement ( $1=$ strongly disagree; $5=$ strongly agree). This instrument has yielded consistent reliability coefficients from previous studies (Thorp, Cummins, \& Townsend, 1998; Bruck, 1997; Taylor, 1998) and more recently Rutherford, Townsend, Briers, Cummins, and Conrad (2002) reported reliabilities ranging from .63 to .83 . A reliability coefficient of 0.70 or higher is considered acceptable, so a range from .63 to .83 suggests a relatively high internal consistency of the construct items and scale reliability (Davis, 1971).

Mean scores, standard deviations, frequiencces, and percentages were analyized in both Excel and SPSS. Analysis and findings will involve aggregate data which does not allow the researcher or any consumer of the research to be able to identify participants responses to any of the questions or survey items.

\section{Results}

Objective one: Identify the demographic characteristics of the animal health interns. 
Student interns represented a cadre of majors with veterinary medicine and animal science being the majority. Other majors included agribusiness, agricultural education and communication, accounting/finance, sales and marketing, biology, agricultural engineering, and poultry science. As highlighted in Table 2, 54\% of the respondents fall between the ages of 22-24, gender was nearly equal in representation, $70 \%$ were Caucasian, and $73 \%$ of the respondents reported being an undergraduate. Additionally, nearly one-third of the respondents reported having previous internship experience.

Table 2

Demographic characteristics of student participants

\begin{tabular}{lll}
\hline Characteristic & $F$ & $\%$ \\
\cline { 1 - 2 } & 15 & 50 \\
$18-21$ & 12 & 40 \\
$22-25$ & 2 & 7 \\
$26-31$ & 1 & 3 \\
Other & & \\
Gender & 14 & 47 \\
Female & 16 & 53 \\
Male & & 73 \\
Academic Level & 22 & 27 \\
Undergraduate & 8 & \\
Graduate & & 13 \\
Ethnicity & 4 & 70 \\
African American & 1 & 10 \\
Asian & 21 & 3 \\
Caucasian & 3 & 73 \\
Hispanic & 1 & 27 \\
Other & & \\
Previous Internship Experience & 22 & \\
Yes & 8 & \\
No & & \\
\hline
\end{tabular}

Note. Total $N=30$.

Objective two: Analyze the perception of leadership and life skills focusing on working with others, decision-making, positional leadership, understanding of self, and communication among the interns. In regard to the LSI respondents agreed or strongly agreed with the following statements: "I can cooperate and work in a group/team", "I feel responsible for my actions", "I use past experiences in making decisions", "I use information in making decisions", "I feel responsible for my decisions", and "I can follow directions"(Table 3). Respondents were in less agreement with the following statements: "I consider all choices before making a decision", "I listen carefully to opinions of group/team members", and "I am a good listener". 
Table 3

Leadership Skills Inventory of all interns

\begin{tabular}{llll}
\hline Statements & SD/D & N & SA/A \\
& $\%$ & $\%$ & $\%$ \\
\hline I can cooperate and work in a group/team & 0 & 0 & 100 \\
I get along with people around me & 0 & 7 & 93 \\
I feel responsible for my actions & 0 & 3 & 97 \\
I believe in dividing the work among group/team & & & \\
members & 0 & 17 & 83 \\
I understand myself & 0 & 17 & 83 \\
I feel comfortable teaching others & 0 & 10 & 90 \\
I consider all choices before making a decision & 7 & 23 & 70 \\
I listen carefully to opinions of group/team members & 7 & 10 & 83 \\
I am respected by others my age & 0 & 10 & 90 \\
I can lead a discussion & 0 & 7 & 93 \\
I use past experiences in making decisions & 0 & 0 & 100 \\
I believe that all group/team members are responsible & & & \\
persons & 3 & 14 & 83 \\
I am sure of my abilities & 0 & 10 & 90 \\
I am a good listener & 7 & 23 & 70 \\
I use information in making decisions & 0 & 3 & 97 \\
I feel comfortable being a group/team leader & 3 & 3 & 93 \\
I accept who I am & 3 & 20 & 77 \\
I feel responsible for my decisions & 0 & 0 & 100 \\
I can give clear directions & 0 & 10 & 90 \\
I can follow directions & 0 & 3 & 97 \\
I can run a meeting & 3 & 7 & 90 \\
\hline
\end{tabular}

Note. Strongly Disagree/Agree $=1-2 ;$ Neutral $=3 ;$ Agree/Strongly Agree $=4-5$.

Objective three: Identify the interns' self-perceived critical thinking skills before and after the completion of a 12 week internship. For all respondents $(N=30)$ the mean pre total score for the UF-EMI was calculated as 104.73 and the mean post total score was calculated as 114.46. Mean scores for the pre critical thinking disposition ranged from a low of 19 to a high score of 87, and the mean scores for the post critical thinking disposition ranged from a low of 13 to a high score of 95 (Table 4). The interns had the highest scores in the engage construct for the pre and post-tests, which means they are able to anticipate situations where reasoning will be necessary to use and are confident communicators. The second highest disposition was cogitative maturity, which suggests awareness of their own predispositions and biases when making decisions. High scores in cogitative maturity also suggest that the interns are aware of complex in-nature problems and there is rarely "one right answer" to problems they may encounter. The innovativeness disposition scores suggest that individuals want to know more and are constantly seeking knowledge through research, reading, and questioning. The UF-EMI uses the CCTDI cutoff points developed by Facione, Facione, and Giancarlo (1998, p.13). 
Table 4

Pre critical think disposition of all interns

\begin{tabular}{llllll} 
Construct & $N$ & Min & Max & $M$ & $S D$ \\
\hline Total & 30 & 87 & 124 & 104.73 & 10.16 \\
Engage & 30 & 35 & 53 & 44.67 & 4.62 \\
Maturity & 30 & 23 & 40 & 31.10 & 4.40 \\
Innovate & 30 & 19 & 35 & 29.53 & 2.71 \\
\hline
\end{tabular}

Post critical think disposition of all interns

\begin{tabular}{lllllll}
\hline Construct & $N$ & Min & Max & $M$ & $S D$ & \%Change \\
\hline Total & 30 & 95 & 128 & 114.46 & 7.95 & 0.077 \\
Engage & 30 & 22 & 53 & 49.25 & 3.68 & 0.077 \\
Maturity & 30 & 18 & 40 & 34.46 & 3.21 & 0.081 \\
Innovate & 30 & 13 & 35 & 31.75 & 2.15 & 6.44 \\
\hline
\end{tabular}

Results of the pre and post sum scores for the critical thinking dispositions of male and female interns in engagement, cognitive maturity, and innovativeness were not significantly differentthus the researcher deemed it unnecessary to post results.

\section{Conclusions/Recommendations}

Fifty-percent of the respondents were between the ages of 18-21and $73 \%$ self-identified as being an undergraduate. Fifty-three percent of the respondents were male; $70 \%$ were Caucasian. This shows a clear lack of diversity within the intern group. There is little to no diversity between the age of interns as well as the ethnicity of interns. To address this, the national animal health internship program should recruit a more diverse intern population in the future to include: a variety of ages, ethnic backgrounds, and previous internship experiences this would better reflect the workforce of a global animal health company. Additionally, a diverse workforce has proven to increase profitability, creativity, learning, and organizational and individual growth (Green, Lopez, Wysocki, \& Kepner, 2002; Thomas \& Ely, 1996).

Self-reported scores on the LSI indicate that the respondents are not fully confident in themselves or their self-awareness - just $77 \%$ of respondents either agreed or strongly agreed that they accept who they are; $20 \%$ chose the neutral response on the survey instrument. There are a cadre of variables that can impact how one perceives themselves and accepts who they are - supervisor feedback or a lack there of, feedback from peers and family, failure in the workplace, failed relationship, etc. We believe there needs to be further study to truly determine the impact(s) - both negative and positive - of the work environment and relationship with an intern supervisor on an intern's perceived self-worth. Results can aid companies in identifying successful intern mentoring and evaluation methods, assist interns in determining what constitutes a successful mentor/mentee relationship, and highlight the professional role(s) interns should model to be impactful and boost one's self-worth. An additional recommendation is to incorporate Emotional Intelligence (EQ) assessments during an internship program - this would 
provide interns a window into their personal and social competence levels and identify how selfawareness and self-management (personal competence), and social and relationship management (social competence) impact their performance in the workplace. According to Bradberry (2014) Emotional Intelligence is the single biggest predictor of performance in the workplace and the strongest driver of leadership and personal excellence.

An additional area of concern regarding LSI scores is that only $70 \%$ of respondents agreed or strongly agreed that they are a good listener; $23 \%$ chose the neutral option, and $7 \%$ disagreed or strongly disagreed with the statement. The challenge for both university faculty and corporate leaders is how to educate and train college students on developing more effective listening skills - a vitally important soft skill for industry success (Crawford, et al., 2011; Moulesong, 2010).

The respondents' self-reported LSI scores regarding teamwork, leading a discussion, and teaching others conflicts with previous research (Brooks, et al., 2008; Crawford, et al., 2011; Klebnikov, 2015). One-hundred percent of the respondents either agreed or strongly agreed that they can cooperate and work in a group/team and $90 \%$ or greater agreed or strongly agreed that they can lead a discussion and feel comfortable teaching others. One may conclude that the interns perceived themselves as being an effective teacher and communicator but in reality they may need additional experience and training. This finding supports the argument that colleges and universities should require students to complete multiple courses that offer opportunities to lead small groups, perform presentations, and partake in experiential learning activities (e.g. externships, internships, study abroad, service learning, etc.).

The UF-EMI utilizes the California Critical Thinking Disposition Inventory (CCTDI) cutoff points developed by Facione to determine a strong, medium, and weak disposition to critical thinking. A UF-EMI total score of 136.95 or higher represents a strong disposition to critical thinking, a score ranging from 135.30-110.55 is moderate, and a score less than 108.9 constitutes a weak disposition to critical thinking. More specifically, the typical ranges for the UF- EMI fall between 28-55 (Engagement), 16-40 (Cognitive Maturity), 15-35(Innovativeness) and a total between 59-130 (Irani, et al., 2007). As reported in Table 4 the total mean score of the pre-critical thinking disposition of all interns was 104.73 - this constitutes a weak disposition to critical thinking. Previous studies discovered similar results when students' critical thinking dispositions were determined by one or more of the following assessments: California Critical Thinking Disposition Inventory (CCTDI) and the Cornell Critical Thinking Test (Bataineh \& Zghoul, 2006; Rudd, Baker, \& Hoover, 2000).The total mean score of the post-critical thinking disposition of all interns was 114.46 which represents a moderate disposition to critical thinking. However, this total group score falls on the bottom end of the scale - a minimum score of 110.55 represents a moderate disposition to critical thinking. The respondents' total mean post score increased by 9.73 which may indicate that the national animal health internship program had an overall positive impact on the participants' engagement, cognitive maturity, and innovativeness dispositions. This increase could be attributed specifically to the structure of the internship program, mentoring, and professional opportunities afforded to each intern. As previously mentioned, dispositions develop over time, are influenced by an individual's surrounding environment, and are strong precursors of critical thinking (Irani, et al., 2007). It must also be noted that standard deviation scores for each construct shrunk on the UF-EMI post-critical 
thinking disposition section compared to the pre-critical thinking disposition section. This too represents a small but important factor regarding the interns' perceived dispositions to critical thinking.

Due to a lack of research regarding the variable(s) that may impact a students' critical thinking dispositions during their tenure in college coupled with industry leaders' desire to attract new hires with strong critical thinking and problem solving skills - longitudinal research is needed to identify which variables (culture, gender, race, experiences, etc.) have the greatest impact on college students' critical thinking dispositions. It is also believed that this type of study - linked with qualitative measures should be replicated to include a cadre of companies representing different industries so as to truly determine the impact(s) of a 12-15 week internship program on interns' perceived communication and leadership abilities.

\section{References}

AACU (2015). Falling short? College learning and career success. Retrieved from https://www.aacu.org/leap/public-opinion-research/2015-survey-results

Adams, C. J. (2012, November 14). "Soft Skills" Seen as Key Element for Higher Ed. Education Week, 32(12), 4 .

Bandura, A. (1986). Social foundations of thought and action: A social cognitive theory. Englewood Cliffs, NJ: Prentice Hall.

Bandura, A. (1977). Self-efficacy: Toward a unifying theory of behavioral change. Psychological Review, 84, 191-215.

Bataineh, R. \& Zghoul, L. (2006). Jordanian TEFL Graduate Students' Use of Critical Thinking Skills (as Measured by the Cornell Critical Thinking Test, Level Z). International Journal of Bilingual Education and Bilingualism, 9(1), 33-50.

Blair, B. F., Millea, M., \& Hammer, J. (2004). The impact of cooperative education on academic performance and compensation of engineering majors. Journal of Engineering Education, 93(4), 333-338. doi:10.1002/j.2168-9830.2004.tb00822.x

Bradberry, T. (2014, January 09). Emotional Intelligence - EQ. Forbes, Retrieved from http://www.forbes.com/sites/travisbradberry/2014/01/09/emotionalintelligence/\#14e487713ecb

Brooks, R., Flanders, A., Jones, M., Kane, S. P., McKissick, J. C., \& Shepherd, T. (2008). A study of the workforce training needs for the agribusiness industry in Georgia.

Bruck, J. (1997). The influence of field dependence on college students' leadership attitudes and Self-perceptions. Dissertations Abstracts International, 58(04), 1181. (UMI no. 9729166)

Coco, M. (2000). Internships: A try before you buy arrangement. SAM Advanced Management 
Journal (07497075), 65(2), 41.

Crawford, P., Lang, S., Fink, W., Dalton, R., \& Fielitz, L. (2011). Comparative Analysis of Soft Skills: What is Important for New Graduates? Washington, DC: Association of Public and Land-grant Universities.

de Ridder J, Meysman P, Oluwagbemi O, Abeel, T. (2014) Soft Skills: An Important Asset. Acquired from Organizing Regional Student Group Activities. PLoS Comput Biol 10(7): e1003708. doi:10.1371/journal.pcbi.1003708

Davis, J. A. (1971). Elementary survey analysis. Englewood Cliffs, NJ: Prentice Hall.

Divine, R. L., Linrud, J. K., Miller, R. H., \& Wilson, J. H. (2007). Required internship programs in marketing: Benefits, challenges and determinants of fit. Marketing Education Review, 17(2), 45-52. doi:10.1080/10528008.2007.11489003

Dobratz, C. L., Singh, R. P., \& Abbey, A. (2014). Using formal internships to improve entrepreneurship education programs. Journal of Entrepreneurship Education, 18(1), 96110.

Driscoll, J. (2006). A century of internships: A quick history of internships and coops in the business world. Retrieved from http://news.pghtech.org/teq/teqstory.cfm?id=1573

Facione, P. A. (1990) Critical Thinking: A statement of expert consensus for purposes of educational assessment and instruction. Research findings and recommendations. (Report No RIEJUN 1990) Millbrae, CA: The California Academic Press. (ERIC Documents Reproduction Service No.ED315423).

Facione, P., Giancarlo, S., Facione, N., \& Gainen, K. (1995). The disposition toward critical thinking. Journal of General Education, 44 (1), 1-25.

Facione, P. A. (1998). Critical thinking: A statement of expert consensus for purposes of educational assessment and instruction: Executive Summary: The Delphi Report. Millbrae, CA: The California Academic Press.

Facione, P. A., Facione, N. C., \& Giancarlo, C. A. (1998). The California critical thinking disposition inventory test manual (Revised). Millbrae, CA: The California Academic Press, Retrieved from http://www.wabash.edu/news/displaystory.cfm?news_ID=2935\#sthash.3pFFMkMm.dpuf

Gault, J., Redington, J., \& Schlager, T. (2000). Undergraduate business internships and career success: Are they related? Journal of Marketing Education, 22(1), 45-53. doi:10.1177/0273475300221006

Green, K.A., Lopez, M., Wysocki, A., \& Kepner, K. (2002). Diversity in the workplace: 
Benefits, challenges, and the required managerial tools. University of Florida ExtensionHRO22. Retrieved from http://citeseerx.ist.psu.edu/viewdoc/download?doi=10.1.1.548.9931\&rep=rep1\&type=pdf

Hart Research Associates, (2015). Falling short? College learning and career success. Selected findings from Online Surveys of Employers and College Students Conducted on Behalf of the Association of American Colleges \& Universities. Retrieved from https://www.aacu.org/sites/default/files/files/LEAP/2015employerstudentsurvey.pdf

Herbert, M. (2009). Student perceptions of the value of internships in business education. American Journal of Business Education, 2(8), 9-13.

Irani, T., Rudd, R., Gallo, M., Ricketts, J., Friedel, C., \& Rhoades, E. (2007). Critical thinking instrumentation manual. Retrieved from http://step.ufl.edu/resources/critical_thinking/ctmanual.pdf.

Klebnikov, Sergei, (2015). What employers are looking for when hiring recent college grads. Forbes. Retrieved from http://www.forbes.com/sites/sergeiklebnikov/2015/07/06/whatemployers-are-looking-forwhen-hiring-recent-college-grads/

Knemeyer, A.M. \& Murphy, P.R. (2001). Logistics internships: Employer perspectives. Transportation Journal. 24(1), 16-26.

Kolb, D. (1984). Experiential Learning. Eagle Wood Cliffs, New York: Prentice Hall.

Mello, J. A. (2006). Enhancing the international business curriculum through partnership with the United States department of commerce: The "E" award internship program. Journal of Management Education. 30(5), 690-699. doi:10.1177/1052562906289049

Moulesong, B. (2010). Listening skills are an important part of effective communication. The Times. Retrieved from http://www.nwitimes.com/business/jobs-andemployment/listening-skillsare-an-important-part-of-effectivecommunication/article_b4d0940a-f919-5d1a-be45 $\underline{05 \mathrm{da} 2 \mathrm{c} 6752 \mathrm{c} 2 . \mathrm{html}}$

Murti, A. B. (2014). Why soft skills matter. IUP Journal of Soft Skills, 8(3), 32-36.

Olson, L. (1993). Creating apprenticeship system will be tough, advocates admit. Education Week,12(1), 29.

Ricketts, J. \& Rudd, R. (2005). Critical thinking skills of selected youth leaders: The efficacy of critical thinking dispositions, leadership, and academic performance. Journal of Agricultural Education, 46(1), 32-43. doi:10.5032/jae.2005.01032

Ricketts, J. Williams, J., \& Priest, K. (2009). Republic of Georgia students' change in 
critical dispositions as a result of a week-long leadership training experience. International Leadership Journal, 1(2), 64-80.

Rudd, R., Baker, M. \& Hoover, T. (2000). Undergraduate agriculture student learning styles and critical thinking abilities: Is there a relationship? Journal of Agricultural Education, 41 (3), 2-12. doi: 10.5032/jae.2000.03002

Rutherford, T. A., Townsend, C. D., Briers, G. E., Cummins, R., \& Conrad, C. R. (2002). Leadership self-perceptions of WLC participants. Journal of Agricultural Education, 43 (2), 22-33. doi: 10.5032/jae.2002.02022

Sides C. H. \& Mrvica A., (2007). Internships: Theory and Practice. Amityville, New York: Baywood.

Smith, J. (2013, May 30). Externships: What they are and why they're important. Forbes. Retrieved from http://www.forbes.com/sites/jacquelynsmith/2013/05/30/externshipswhat-theyare-andwhytheyre-important/\#7a8d20d929b9

Snell, K. D. (1996). The apprenticeship system in British history: the fragmentation of a cultural institution. History of Education, 25(4), 303-321. doi: 10.1080/0046760960250401

Swift, C., \& Kent, R. (1999). Business school internships: Legal concerns. Journal of Education for Business, 75(1), 23. doi: 10.1080/08832329909598985

Taylor, J. (1998). Leadership skills and attitudes perceived by collegiate male students. Dissertation Abstracts International, 59(4), 1096. (UMI No. 9830990).

Taylor, M. S. (1988). Effects of college internships on individual participants. Journal of Applied Psychology, 73(3), 393-401.

Thiel, G. R., \& Hartley, N. T. (1997). Cooperative education: A natural synergy between business and academia. S.A.M. Advanced Management Journal, 62(3), 19-24.

Thomas, D. \& Ely, R. (1996). Making differences matter: A new paradigm for managing diversity. Harvard Business Review. Retrieved from http://s3.amazonaws.com/academia.edu.documents/33149013/MAKING_DIFFERENCE S_DIFFERENT.pdf?AWSAccessKeyId=AKIAJ56TQJRTWSMTNPEA\&Expires=14691 28076\&Signature $=86 \mathrm{pNHDuYoFZf15qr61NXbLrVqpw \% 3D \& response-content}$ disposition=inline\%3B\%20filename\%3DMaking_Differences_Matter_A_New_Paradigm .pdf

Thorp, L, Cummins, R., \& Townsend, C. (1998). Women's self-perceived leadership skills in a collegiate agricultural education course. Journal of Agricultural Education, 39 (1), 55-62. doi: $10.5032 /$ jae.1998.01055

Townsend, C. (1981). FFA participation and personal development as perceived by Iowa 
vocational agriculture seniors. Unpublished doctoral dissertation, Iowa State University, Ames.

Townsend, C. D., \& Carter, R. I. (1983). The relationship of participation in FFA activities and leadership, citizenship, and cooperation. Journal of the American Association of Teacher Educators in Agriculture, 24(1), 20-25. doi: 10.5032/jaatea.1983.01020

Tyagi, K., \& Tomar, A. (2013). Soft skills for successful career. Pertanika Journal of Social Sciences \& Humanities, 21(1), 341-350.

Walker, B. F., Morgan, A. C., Ricketts, J. C., \& Duncan, D. (2007). Proceedings from ALE 2007 Association of Leadership Educators. Ft. Worth, TX.

Walker, R. (2011). Business internships and their relationship with retention, academic performance, and degree completion, (Unpublished masters's thesis). Iowa State University, USA.

Weible, R. (2009). Are universities reaping the available benefits internship programs offer? Journal of Education for Business, 85(2), 59-63. doi: 10.1080/08832320903252397

Workforce Solutions Group (2015). State of St. Louis workforce 2015; examining the opportunity gaps (Report 1) Retrieved from St. Louis Community College http://www.stlcc.edu/Workforce-Solutions/Workforce-Data/Employer$\underline{\text { Survey.html }}$

\section{Author Biographies}

Dennis W. Duncan is a Professor of Leadership Studies at the University of Georgia and Coordinator of the uLEAD Leadership and Service Certificate Program. He has 21 years experience teaching leadership and communication-based courses and his research interests include determining impacts of service learning and study abroad programs.

Victoria Birdsong completed her Master of Leadership Degree Program at the University of Georgia and is currently a Diabetes Sales Representative with Eli Lilly and Company.

Dr. Fuhrman is an Associate Professor in the Department of Agricultural Leadership, Education, and Communication at the University of Georgia. He holds a Ph.D. in Agricultural Education and Communication from the University of Florida and teaches courses on environmental education, program development, and data analysis.

Dr. Abigail Borron is an Assistant Professor of Agricultural Communication in the Department of Agricultural Leadership, Education, and Communication at the University of Georgia. Her research focuses on culture-centered communication with emphases in marginalized audiences, food insecurity, and university engagement. 